\title{
Study on Consumptive Use of Water of Kangkong
}

\author{
Thanwamas Kassanuk ${ }^{1}$, Khongdet Phasinam ${ }^{2}$ \\ 1,2 School of Agricultural and Food Engineering, Faculty of Food and Agricultural Technology, Pibulsongkram Rajabhat \\ University, Thailand \\ t.kassanuk@gmail.com, ${ }^{2}$ phasinam@psru.ac.th
}

\begin{abstract}
The aim of this research was to evaluate the irrigation consumption for the growth of Kangkong (Ipomoea aquatica Forsk. Var. reptan). The system based on drip irrigation for crops. Drip irrigation system consisted of a 16-liter water tank, a water supply facilities and water supply systems. The water tank is raised $1,000 \mathrm{~mm}$ above the ground, connected by a $18 \mathrm{~mm}(1 / 2 \mathrm{in})$ PVC pipe at the conversion head. Drip tape is paying a hole measuring $100 \mathrm{~mm}$. The rate of water distribution is equal to 2.20 liters per hour, consisting of 6 lines. Each line had a distance of $200 \mathrm{~mm}$, according to the plantation. According to the characteristics of the plot, which had 60 wells and provides 25 days of water throughout the harvest of Kangkong. The research found that water consumption of Kangkong average of $108.5 \mathrm{~mm}$ or 4.4 millimeters per day. The average height was 334 millimeters per plant. The average weight was 8.96 grams per plant. The average root length was $89.6 \mathrm{~mm}$. Number of leaves was 12 per plant. The average leaf length was $131.3 \mathrm{~mm}$ and the average yield of Kangkong throughout the season was $4.93 \mathrm{~kg}$
\end{abstract}

Keywords

Kangkong, Plant Growth, Irrigation

Article Received: 10 August 2020, Revised: 25 October 2020, Accepted: 18 November 2020

\section{Introduction}

Kangkong (Ipomoea aquatica Forsk. Var. reptan.) can be planted all year round. It can grow in almost all soil types, especially for soil with high moisture content [1]. The maturity is short, 20-30 days [2]. In addition, Kangkong is also highly nutritious. It is beneficial for the body, helps maintain health, contains vitamin A that is beneficial for the eyes, high in dietary fiber and contains important nutrients including protein, calcium, iron, and phosphorus, etc. [3]. It also helps appetite and neutralizes the body [4]. It is a plant that is popular to produce for household consumption and commercially produced. Commercial production will be exported in the form of fresh plants and seeds are abundant in South and Southeast Asia [5], [6].

Water is the main factor for growing plants. When the plants receive sufficient and appropriate water for the time required by the plants, rich in nutrients, and have appropriate weather conditions, they can photosynthesis to produce food for use in growth and fully store nutrients. However, if growing plants that rely solely on seasonal rainwater, they may be prone to dehydration for some time [7]. The system of watering plants is a mechanism that can manage and control the amount of watering plants properly, conveniently, and with good results, can meet the needs of plants adequately. The methods of watering plants can be divided into four types: 1) surface watering, 2) sprinkling, 3) drip irrigation, and 4) subsurface watering. For drip irrigation, the plants are watered at one or more points on the soil surface or in the root zone. The water that is given to plants is in the form of small water beads, which are injected from a small nozzle that requires not much pressure or as a drop of water or a small stream of water flowing from a hose, nozzle, or plastic pipe [8]. Moreover, the drip irrigation system is a watering system with high water efficiency, low water consumption, and low water pressure. It can be used well with all types of plants and soils [9].
Therefore, this research aims to study water consumption for the growth of Kangkong. This can be used as information for farmers and people who are interested in general.

\section{Research Objectives}

The objective of this research is to study the water consumption of Kangkong during the harvesting period.

\section{Research Methods}

\section{A. Soil Analysis}

Soil analysis was performed by sampling the soil by equal interval on diagonal lines [10] as shown in Fig. 1 at depths 0 $\mathrm{cm}, 5 \mathrm{~cm}, 10 \mathrm{~cm}, 15 \mathrm{~cm}, 20 \mathrm{~cm}$, and $25 \mathrm{~cm}$ deep. The soil samples were then used to analyze the properties of the soil texture, soil chemistry, and plant nutrients in the soil.

\section{B. Design of Planting Plots and Watering Systems}

The Kangkong planting plot is designed as a rectangle, 100 $\mathrm{cm}$ wide, $150 \mathrm{~cm}$ long. The plot is $25 \mathrm{~cm}$ deep and laid with a clear plastic sheet at the bottom to support the water as shown in Fig. 2. At the end of the plot, there is a $18 \mathrm{~mm}(1 / 2$ in) PVC pipe to support the water from the planting area and transfer the water to a $1,200 \mathrm{~mL}$ measuring cylinder, which is used to measure the amount of water leftover from the planting plot. Then lift the planting plot to a height of $15 \mathrm{~cm}$ from the original ground level. The cultivation of Kangkong was carried out by sowing seeds into holes and covering 90 seeds, each with a distance of $10 \mathrm{~cm}$. Designing a system for watering plants using a drip irrigation system, which the system will provide water using the principle of water flow from gravity. By designing the drip irrigation system, a 16liter water tank was chosen as a water reservoir and supplying water to plants throughout the plot, which the 
water tank is raised $100 \mathrm{~cm}$ above the floor, connect with 18 $\mathrm{mm}(1 / 2$ in) PVC pipe at the conversion head. Using drip tape with $100 \mathrm{~mm}$ drip emitters in the emitters flow rate equal to 2.20 liters per hour, number of 6 lines, which can be obtained from (1), each line has a distance equal to $200 \mathrm{~mm}$, according to the nature of the planting plot as shown in Fig. 3 and Fig. 4.

\section{Determination of Water Consumption of Kangkong}

When designing Kangkong plantations and install a drip irrigation system, then calculate the amount of water that must be given to Kangkong. Starting with finding the wet area according to (2). Then determine the preliminary water needs of Kangkong, which is equal to 3 millimeters per day. The plants will consume $3 \mathrm{~mm}$ to $5 \mathrm{~mm}$ of water per day, to find out the precipitation rate as (3) [9], and find the amount of water needed for plants as (4), which is equal to 110 millimeters per day. Then experimented with watering Kangkong to determine the water consumption of Kangkong each day. By recording the excess water flowing from the plant field into the measuring cylinder at the end of the planting plot, in order to calculate the amount of water consumption of Kangkong

\section{Growth and Productivity of Kangkong}

The study of the growth and yield of Kangkong during the harvesting period was 25 days. Data were collected and recorded every 7 days consist of stem height, average weight per plant, number of leaves per plant, root length, and yield of Kangkong during the harvesting period.

Number of drip tape $=\left(\frac{\text { plot width }}{\text { drip tape laying distance }}\right)+1$

Wet zone $=$ drip tape length $\times$ wet zone width

Precipitation rate $=\frac{\text { water volume from tank }}{\text { wet area }}$

Consumptive water use $=\frac{\text { daily consumptive water use }}{\text { precipitation rate }}$

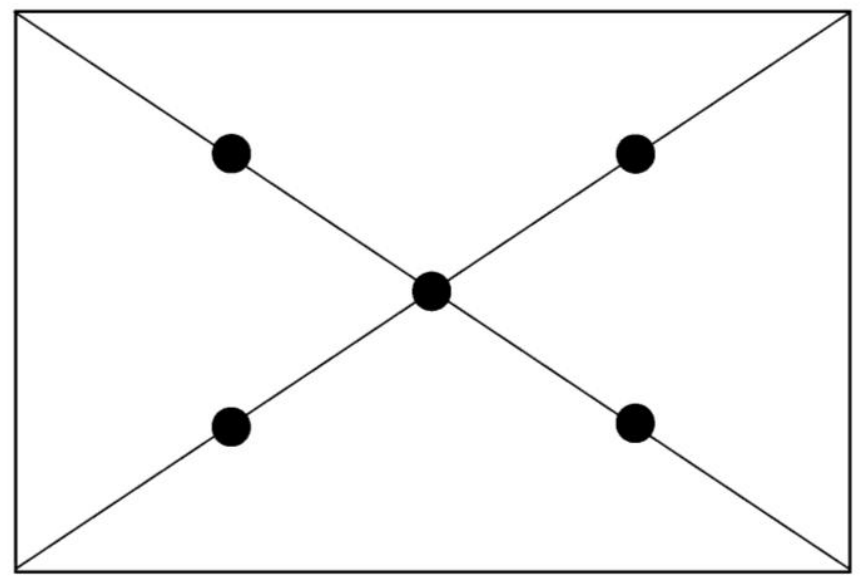

Fig. 1 Schematic of soil sampling positions

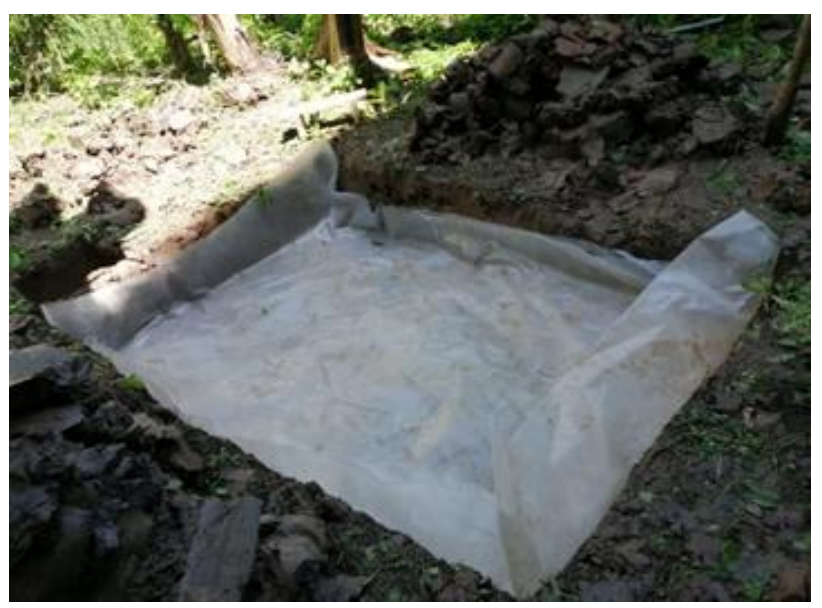

Fig. 2 Lay the plastic sheet on the ground plot

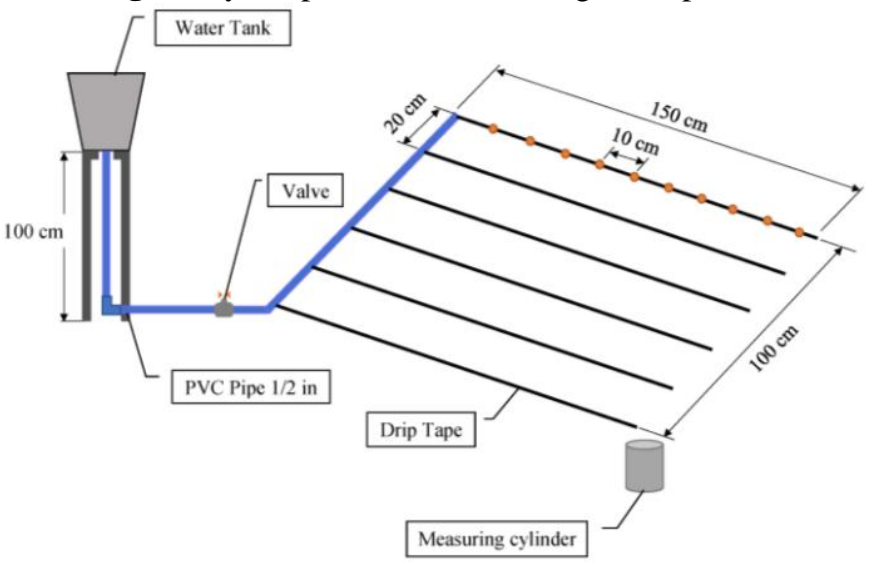

Fig. 3 Layout of drip irrigation system

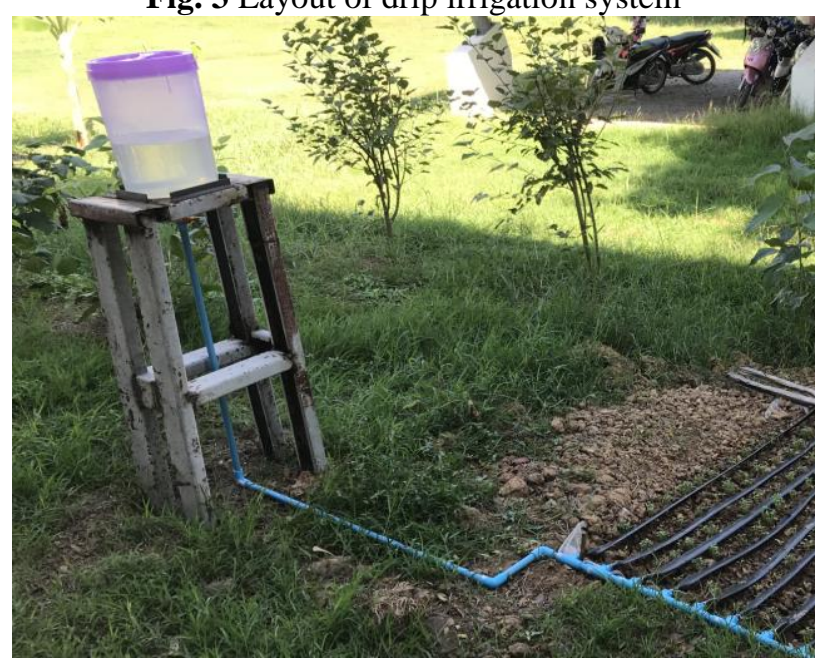

Fig. 4 A self - made drip irrigation system

\section{Results}

The study of water consumption of Kangkong by drip irrigation system was divided into 4 parts as follows: 1) soil analysis showed that soil properties were 85.61 percent clay, 4.36 percent sand, and 10.03 percent silt. Used in the test is neutral $\mathrm{pH}$ and plant nutrients in the soil found that ammonia is low. Phosphorus is high and high levels of potassium. 2) design of planting plots and irrigation systems. The plant plots have an area of 1.5 square meters. The irrigation system is a drip system. Which uses a 16 liters water tank as a water reservoir and supplies water to the system. The water tank is raised $1,000 \mathrm{~mm}$ from the 
floor, connected by $18 \mathrm{~mm}(1 / 2 \mathrm{in})$. PVC pipe at the conversion head and using a drip tape with a $100 \mathrm{~mm}$ drip emitters in the emitters flow rate equal to 2.20 liters per hour, 6 lines, each with a distance of $200 \mathrm{~mm}$. 3) water consumption of Kangkong was found that water consumption for the growth of Kangkong during 25 days of harvest was $108.50 \mathrm{~mm}$ or 4.40 millimeters per day as shown in Table I and 4) productivity of Kangkong. The growth and yield of Kangkong was found that the average stem height was 334 millimeters per plant. The average weight of 8.96 grams per plant, the average number of leaves 12 leaves per plant, the average leaf length $13.13 \mathrm{~cm}$, the average root length 139.4 millimeters per plant and the yield of Kangkong during harvest was $493 \mathrm{~g}$ or 382.67 grams per square meter as shown in Table II.

Table I The consumptive use of water of Kangkong

\begin{tabular}{lccc}
\hline \multicolumn{1}{c}{ Time } & $\begin{array}{c}\text { Number } \\
\text { of days }\end{array}$ & $\begin{array}{c}\text { Consumptive } \\
\text { use per day } \\
(\mathbf{m m})\end{array}$ & $\begin{array}{c}\text { Total of the } \\
\text { consumptive use } \\
(\mathbf{m m})\end{array}$ \\
\hline 19-26 Sep. 19 & 7 & 3.80 & 26.60 \\
27 Sep.-2 Oct. 19 & 7 & 4.31 & 30.17 \\
3-9 Oct. 19 & 7 & 4.59 & 32.13 \\
10-13 Oct. 19 & 4 & 4.90 & 19.60 \\
\hline Average & & $\mathbf{4 . 4 0}$ & $\mathbf{1 0 8 . 5 0}$ \\
\hline
\end{tabular}

Table II Growth and yield of Kangkong during harvesting period.

\begin{tabular}{lc}
\hline \multicolumn{1}{c}{ Indicator (associated variable) } & Value \\
\hline The yield weight per plot $(\mathrm{kg})$ & 4.93 \\
The average plant height $(\mathrm{mm})$ & 334.00 \\
The average plant weight $(\mathrm{g})$ & 8.96 \\
The average root length $(\mathrm{mm})$ & 139.40 \\
The average number of leaves (leaves) & 12.00 \\
The average leaf length $(\mathrm{mm})$ & 131.30 \\
\hline
\end{tabular}

\section{Discussions}

From the research results, it was found that water consumption of Kangkong during the 25 day harvesting period was $108.5 \mathrm{~mm}$ or the average daily water consumption was $4.40 \mathrm{~mm}$ consistent with M. Kongkaew and other [11] that water consumption of Kangkong was studied by drip irrigation. It was found that water consumption of Kangkong 24 days after planting had an average water usage value of $106.5 \mathrm{~mm}$ or 4.44 millimeters per day. The growth of Kangkong was found to be consistent throughout the harvest period. The average stem height is 334 millimeters per plant. The average weight was 8.96 grams per plant. The number of leaves per plant was 12.00 , the leaf length was $13.13 \mathrm{~cm}$ and the yield during the harvest was 493.00 grams consistent with the articles of C. Sudchit [12]. Which has reported information on the composition of the Kangkong, which grows 20 to 25 days throughout the harvest, has a plant height or length of 30-35 $\mathrm{cm}$, and leaves $7-15 \mathrm{~cm}$ in length. The management of watering plants is important to affect crop yields. Therefore, if the plants receive the right amount of water for the time required by the plants rich in nutrients and have appropriate weather conditions plants grow quickly and produce high yields [13].

\section{Recommendations}

\section{A. Recommendations for Practices}

Kangkong is a plant that has a short harvest time, high nutritional value, low water consumption, and less disturbing pests. Therefore, farmers and those interested in plants should be encouraged to generate income or create a career.

\section{B. Recommendations for Further Research}

Study of water consumption of Kangkong further studies of other factors related to growth such as evaporation rate and soil moisture etc.

\section{Conclusion}

Water consumption of Kangkong by drip irrigation system was found that water consumption of Kangkong was used for 25 days of harvest, the average water consumption was $108.5 \mathrm{~mm}$ or 4.40 millimeters per day. The average stem height is 334 millimeters per plant. The average weight was 8.96 grams per plant, the average root length was 139.4 millimeters per plant. The average number of leaves was 12 leaves per plant, the average leaf length was $131.3 \mathrm{~mm}$ and the yield of Kangkong during the harvest was 493.00 grams or 328.67 grams per square meter.

\section{References}

[1] O. Anugoolprasert, P. Bunwatthanakul and S. Chakhatrakan, "Effects of High Quality Organic Fertilizer, Chemical Fertilizer and Their Combinations on Growth and Yield of Kangkong (Ipomoea aquatica Forsk.)", Science and Technology Journal, vol. 23, pp. 969-982, 2015.

[2] G. Owens, "Kangkong", Northern Territory Government, 2006.

[3] K.J. Umar, L.G. Hassan, S.M. Dangoggo and M.J. Ladan, "Nutritional Composition of Water Spinach (Ipomoea aquatica Forsk.) Leaves", Journal of Applied Sciences, vol.7, pp. 803-809, 2007.

[4] E. Sarepoua, P. Khaengkhan and C. Aekaraj, "Effects of Varieties and Seedling Medias on Growth and Yields in Water Convolvulus Sprouts Production", Khon Kaen Agriculture Journal, vol.46, pp. 543-548, 2018.

[5] V. Chaichana, "Efficiency of Vermicompost on Growth and Yield of Water Kangkong (Ipomoea aquatica Forsk. 
Var. reptan)", Prawarun Agricultural Journal, vol.16, no.1, pp. 81-90, 2019.

[6] M.C. Palada and L.C. Chang, "Suggested Cultural Practices for Kangkong", Asian Vegetable Research and Development Center 1971, 2003.

[7] C. Yenyongsawad P. Sophanodora, W. Wanchit and V. Somsap, Water and Irrigation. Faculty of Natural Resources., SK. [online] Available: http://natres.psu.ac.th/Department/plantsci ence/510-

$111 \mathrm{web} / \mathrm{book} / \mathrm{book} \% 20$ content.htm/chapte r09/agri_09.htm

[8] V. Vudhivanich, N. Cherdchanpipat and P. Sopaphan, "Introduction to Irrigation Engineering", Nakhonpathom: Kasetsart University, 2015, pp. 224-225.

[9] T. Kaikaew and K. Khongman. (2019, May.). Drip Irrigation System Manual. Agricultural Land and Office., BK. [Online]. Available: https://www.alro.go.th.

[10] J. Prasopsuk. (2020, Jul.). Samples of Soil, Water and Plants Testing and Analysis. Office of Agricultural Research and Development Region 3., KKN. [Online]. Available:

http://oard3.doa.go.th/oard3/pdf/jarupong2 .pdf

[11] M. Kongkaew, W. Kongkaew, S. Kaewsasaen, and S. Charoonsak. (2010). Study on Consumptive Use of Water Convolvulus. Agricultural Royal Irrigation Department., BK. [Online]. Available: http://kmcenter.rid.go.th/kchydhome/docu ments/2553/study/PDF0008.pdf

[12] C. Sudchit, "Storage productivity of Kangkong (Ipomoea aquatica Forsk. Var. reptan) in Experimental Research of Irrigation", Irrigated Agriculture Newsletter, vol.17, pp. 2-8, 2013.

[13] Burean of Agricutural Commodities Promotion and Management. (2016, Dec.). Using of water worthily for growing plants. Department of Agricultural Extension., BK. [Online]. Available: https://esc.doae.go.th 